岡山医誌（1992） 104，989 990

\title{
11）肝細胞癌における $\mathrm{HBV}, \mathrm{HCV}$ 重複感染についての検討
}

\author{
香川医科大学第三内科学教室 \\ 伊藤 哲史, 桶本 尚志, 高瀬 泰造, 有馬 啓治 \\ 渡辺精四郎，西岡 幹夫
}

(平成 4 年 7 月 27 日受稿)

Key words：肝細胞癌, $\mathrm{HBV}, \mathrm{HCV}$

\section{緒}

폴

肝細胞癌における肝炎ウイルス, 特に B 型肝 炎ウイルス $(\mathrm{HBV})$ と C 型肝炎ウイルス $(\mathrm{HCV})$ の重複感染について検討し若干の知見を得たの で報告する。

\section{対象と方法}

当科で過去 3 年間に肝細胞癌と診断した 93 症 例（男性69例，女性24例），平均年齢61.7歳）に ついて, 血清中の HBs 抗原 (RPHA) と HCV C100抗体 (ELISA) を測定し, さらに RIBA

(Ortho 社)に上る HCV 抗体確認試験と non coding region $の$ primer を使用した RT-PCR 法により，血中 HCV-RNAの検出を行なった.

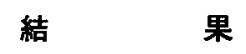

当科における肝細胞癌での HBs 抗原と HCV 抗体の陽性率を表 1 に示寸. HBs 抗原の陽性率 は $26.9 \%, \mathrm{HCV}$ 抗体の陽性率は $58.1 \%$ であった。

表 1 肝細胞癌における HBs Ag と HCV Abの陽 性率

\begin{tabular}{lccc}
\hline & $\mathrm{HCV} \mathrm{Ab}(+)$ & $\mathrm{HCV} \mathrm{Ab}(-)$ & Total \\
\hline $\mathrm{HBs} \mathrm{Ag}(+)$ & 5 & 20 & 25 \\
& $(5.4 \%)$ & $(21.5 \%)$ & $(26.9 \%)$ \\
\hline \multirow{2}{*}{$\mathrm{HBs} \mathrm{Ag}(-)$} & 49 & 19 & 68 \\
& $(52.7 \%)$ & $(20.4 \%)$ & $(73.1 \%)$ \\
\hline \multirow{2}{*}{ Total } & 54 & 39 & 93 \\
& $(58.1 \%)$ & $(41.9 \%)$ & $(100 \%)$ \\
\hline
\end{tabular}

HBs 抗原, HCV 抗体ともに陽性は 5 例で，こ れは HBs 抗原陽性25症例の $20 \%$ に相当した。 この 5 症例について検討すると, HCV-RNA が 検出されたのは 1 例（20\%）のみであった（表 2).また,このうち HCV-RNA の検出されな い 4 例では, HCV 抗体測定時の吸光度は 0.49 1.14と低く, RIBA 法ではいずれも陰性 であった.さらに, HBV 関連マーカーをみると, HBe 抗原陽性例と HBe 抗体陽性例が 2 例ずつ であった.

\section{考察}

HCV に対する抗体の測定が可能となり，各種 慢性肝疾患における陽性率が明らかになってき た1．また，HBV との重複感染の頻度について も検討され，本邦での HBs 抗原陽性慢性肝炎 での HCV 抗体の陽性率は $3.9 \%$ と報告されてい $る^{2)}$. しかし, 肝細胞癌合併例では $33 \%^{\mathrm{s})} \sim 52.4$ \%)と高率であり,ウイルスの重感染が発癌を促 進している可能性が示唆されている。

一方，中西らは4)，ELISA 法による HCV 抗 体の測定結果は, GOR 抗体, HCV-PHA, EIA -IIでの測定結果と解離し, しかもその頻度は高

表 2 肝細胞癌における HCV-RNA の検出率

\begin{tabular}{lcc}
\hline & $\mathrm{HCV} \mathrm{Ab}(+)$ & $\mathrm{HCV} \mathrm{Ab}(-)$ \\
\hline $\mathrm{HBs} \mathrm{Ag}(+)$ & $20.0 \%$ & $0 \%$ \\
\hline $\mathrm{HBs} \mathrm{Ag}(-)$ & $83.3 \%$ & $21.1 \%$ \\
\hline
\end{tabular}


率であり，ELISA 法による HCV 抗体の測定 では, B 型肝細胞癌症例で偽陽性が多いと指摘 している。また，HBV と HCV には千涉作用 があり, HBe 抗原陽性例では血中に HCV-RNA が検出されない可能性もある22.

当科で経験した $\mathrm{HBs}$ 抗原, $\mathrm{HCV}$ 抗体ともに 陽性 5 例では, HCV-RNA が検出されたのは 1 例のみであった. HCV-RNAの検出されない 4 例は, RIBA 法で陰性でうち 2 例が $\mathrm{HBe}$ 抗体 陽性であった.これらの症例は, $\mathrm{HBV}$ の存在に より $\mathrm{HCV}$ の増殖が抑えられているために $\mathrm{HCV}$ -RNA が検出されないのではなく，ELISA 法 の偽陽性と考えるのが適当で，他地区における $\mathrm{B}$ 型肝細胞癌での $\mathrm{HCV}$ の重複率は $4.0 \%$ にす ぎないと考えられた。

しかし, 肝細胞癌における HCV の感染の検 討は，現在の抗体測定法や HCV-RNA の検出
をもっても十分とは言えない.また，HBs 抗原 が陰性であっても肝組織中に HBV-DNA が検 出される ${ }^{5)}$,という報告や, 一過性感染でも host genome に組み込まれた HBV-DNA が発癌因 子となることも考えられ, 两ウイルスの重感染 の頻度や, 重感染が発癌を促進するか否につい ては, さらに詳細な検討が必要であると考えら れる。

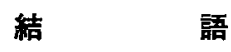

1. 当科の肝細胞癌での HBs 抗原陽性率は 26.9\%で，C100抗体陽性率は58.1\%であった。 また，ともに陽性は $5.4 \%$ であった。

2. HBs 抗原陽性肝細胞癌での C100抗体陽 性率は20\%であったが, HCV-RNA の検出率は $4 \%$ \%すぎす，両ウイルスの重複感染の頻度は 高くなかった。

\section{文献}

1）飯野四郎, 他：第16回犬山シンポジウム記録（1990)，160.

2）茶山一彰, 他：日消誌 (1991) 88，2113.

3 ）金子周一, 他：臨床科学 (1990) 26, 1555.

4）中西敏夫, 他：岡山医誌（1991）103，1039.

5）結城啺一, 他：日消誌 (1990) 87，2466. 